\title{
NASIONALISME ASIA TIMUR: SUATU PERBANDINGAN JEPANG, CINA, DAN KOREA
}

\author{
Oleh: Mudji Hartono*
}

\begin{abstract}
Abstrak
Kebangkitan nasional di Asia Timur telah muncul pada pertengahan abad ke-19 dan awal abad ke-20 sejalan dengan semakin intensifnya usaha penguasaan wilayah oleh suatu bangsa terhadap bangsa lain. Walaupun sama-sama bangsa Asia Timur, namun yang mendasari terbentuknya nasionalisme antara Jepang, Cina, dan Korea tampak adanya perbedaan. Untuk itu, dalam rangka melihat identitas masing-masing negara tersebut terkait dengan munculnya nasionalisme, artikel ini mencoba mengkajinya.

Dari hasil kejian tampak bahwa di Jepang pembentukan nasionalisme didasarkan pada gabungan unsur etnisitas dan loyalitas politik. Sementara itu, di Cina dan Korea hanya aspek loyalitas politik yang digunakan untuk membentuk nasionalisme. Di Jepang, kedua unsur itu telah menyatu pada diri orang Jepang, sehingga apa yang dilakukan oleh orang Jepang yang berorientasi internasionalisme tidak melenyapkan identitas nasional. Mereka sadar betul bahwa dirinya adalah orang Jepang. Sebaliknya, sebenarnya hingga saat ini pembentukan "nasionalisme Cina" dan "nasionalisme Korea” belum dapat terwujud.
\end{abstract}

Kata Kunci: Cina, Etnisitas, Jepang, Korea, Loyalitas Politik, dan Naionalisme

\section{A. Pendahuluan}

Pada umumnya nasionalisme bermakna melahirkan perasaan cinta tanah air dalam upaya membentuk sebuah negara bangsa. Kata nasionalisme berhubungan dengan dua hal, yaitu kewargaan negara dan semangat patriotik. Kewargaan negara menuntut soal politik dan kedaulatan kemerdekaan. Semangat patriotik menuntut soal cinta tanah air. Dengan kata lain, nasionalisme adalah sentimen kesetiaan atau simpati yang mengikat suatu bangsa berdasar institusi dan budaya yang sama untuk mewujudkan persatuan dan mencapai terbentuknya negara bangsa (Nation State) yang merdeka.

*'Dosen Prodi Ilmu Sejarah Jurusan Pendidikan Sejarah FISE UNY. 
Pembentukan nasionalisme di Asia sering dihadapkan dengan kolonialisme Barat atau merupakan reaksi atas kehadiran kolonialisme Barat. Namun kini terdapat perkembangan lain, pembentukan nasionalisme di kawasan Asia Timur terjadi beberapa kali. Sebelum tahun 1945 hanya Cina yang dijajah oleh bangsa Barat, itupun tidak seluruh wilayah didudukinya, maka bentuk penjajahan itu disebut semi- kolonial. Jepang tidak pernah dijajah bangsa Barat tetapi ancaman penjajahan bangsa Barat yang menimbulkan nasionalisme. Korea beberapa kali diduduki oleh Cina, dan yang terakhir dijajah Jepang (1910-1945). Nasionalisme di Korea muncul karena ingin melepaskan diri dari penjajahan Jepang. Setelah tahun 1945 Jepang di bawah pendudukan Amerika Serikat namun hanya menimbulkan kekhawatiran sekejap, dan tidak menimbulkan gerakan anti Amerika. Begitu pula Korea sebelum perang saudara, meskipun berada di bawah tentara pendudukan, yaitu AS di Korea Selatan dan Uni Soviet di Korea Utara, tetapi gerakan anti asing tidak muncul dengan serius.

Apabila merujuk kepada pengertian kolonialisme yang lebih luas maka sebenarnya negeri Cina dijajah oleh dua bangsa secara bersamaan. Pada tahun 1644-1911 Cina dijajah oleh bangsa Manchu yang notabene bukan asli Cina. Pada pertengahan abad ke-19 bangsa Barat mulai menjajah Cina, sehingga perjuangan nasionalisme Cina berhadapan dengan bangsa Barat di satu pihak dan pemerintahan feudal di pihak lain.

Kebangkitan nasional di Asia Timur telah muncul pada pertengahan abad ke-19 dan awal abad ke-20 sejalan dengan semakin intensifnya usaha penguasaan wilayah oleh bangsa asing terhadap bangsa lain. Di Asia Timur ( Cina, Korea dan 
Jepang ), proto nasionalisme terbentuk dari gabungan unsur-unsur: etnisitas dan tradisi negara. Dalam hal ini sangat mungkin apabila kesukuan dan loyalitas politis saling terkait. Apakah hal ini masih berlaku juga pada akhir abad ke-20? Hal ini dipertanyakan mengingat nasionalisme itu dinamis dan berubah sesuai dengan perkembangan zaman.

\section{B. Nasionalisme Jepang}

Pembentukan nasionalisme Jepang agak berbeda dengan di Cina dan Korea. Jepang tidak pernah dijajah oleh bangsa asing. Jepang merupakan negara merdeka dan berdaulat. Nasionalisme lahir dengan tujuan untuk mengekalkan kedaulatannya dan berupaya membendung serta mengelakkan diri dari ancaman kolonialisme Barat. Kemunculan nasionalisme Jepang itu terlihat dengan jelas saat datangnya C. Perry (1854), walaupun sebenarnya fondasi nasionalisme telah terbentuk sejak Politik Isolasi (sakoku) diterapkan Jepang pada abad ke-18. Rupanya kokka shugi, artinya 'negara-keluarga-isme', adalah kata yang pantas digunakan pada saat itu. Ketika itu Jepang dikuasai oleh keluarga Tokugawa, dan berupaya mengamankan Jepang dari ancaman penjajahan bangsa Barat, terutama Portugis, yakni dengan cara menerapkan Politik Isolasi. Dalam isolasi itu berlangsung proses pembentukan jiwa ke-Jepang-an pada bangsa Jepang. Selanjutnya, kedatangan C. Perry merupakan ancaman penjajahan Barat yang kedua kalinya. Oleh karena Politik Isolasi dipandang gagal dan sudah tidak sesuai dengan perkembangan dunia maka harus digantikan dengan modernisasi. Maka 
kokka shugi tidak lagi dipergunakan dan digantikan nashonarizumu, atau kokumin-shugi , artinya “rakyat-negara-isme”. ${ }^{1}$

Penolakan terhadap ancaman bangsa Barat itu dilakukan dengan modernisasi, dan ketika itu pula semangat nasionalisme ditiupkan lebih kencang. Gerakan nasional selama satu dasawarsa pertama Restorasi Meiji menjadi tonggak yang sangat penting bagi Jepang. Kaum pembaharu melakukan restorasi yang diawali oleh suatu "Revolution from Above”. Mereka sebagai pelopor pergerakan nasional, mereka berasal dari golongan samurai yang termasuk klas atas, dan mereka melakukan perubahan secara cepat yang diarahkan dari atas ke bawah. ${ }^{2}$ Dengan merujuk pada tiga slogan nasional, yaitu Isshin (kembali ke masa silam), Sonno-joi (hormati Kaisar dan usir orang-orang biadab) dan Fukoku Kyohei (militer kuat, negara sejahtera), maka akan tampak jelas bahwa pembentukan nasionalisme didasarkan pada unsur-unsur etnik, budaya dan politik. Ketiga unsur saling berkaitan satu sama lainnya, bahwa pandangan bangsa Jepang adalah kaisar sebagai pemimpin tertinggi, orang Barat sebagai bar-bar dan kedaulatan negara harus dipertahankan. Proses pembentukan nasionalisme itu dimulai dari golongan samurai dengan pengorbanan demi memelihara dan meningkatkan kesejahteraan nasional. $^{3}$

Dengan demikian Restorasi Meiji (1868) tidak hanya bertujuan untuk menunjukkan reaksi terhadap kedatangan bangsa Barat di Jepang, melainkan juga

${ }^{1}$ Edwin O. Reischauer. Manusia Jepang. Jakarta: Sinar Harapan, 1982., hlm. 544.

${ }^{2}$ Mudji Hartono. ”Dasawarsa Pertama Restorasi Meiji (1868-1878): Sebuah Kasus Revolusi Dari Atas”, dalam Informasi No.2 Th.XVII, 1987. Lihat juga : Jr. Barrington Morre. Social Origin of Dictatorship and Democracy. Boston: Beacon Press, 1967, hlm. 228.

${ }^{3}$ Ruth Benedict, Pedang Samurai dan Bunga Seruni, Pola-Pola Kebudayaan Jepang. Jakarta: Sinar Harapan, 1979, hlm. 88 
upaya pembentukan kembali nasionalisme. Modernisasi menjadikan Jepang sebagai negara kuat sejajar dengan Barat pada awal abad ke-20. Jepang, walaupun jelas tipe asli tersendiri (sui generis), dapat diberi gelar kehormatan sebagai suatu kekuatan imperial Barat, dan karenanya bisa disebut sebagai negara nasional atau nasionalis seperti model Barat yang ditirunya.

Semangat nasionalisme Jepang pada tahun 1930-an dan 1940-an menjadi sangat tinggi, ekstrem dan agresif atau ultranasionalisme. Kaum ultrnasionalis mempunyai cita-cita meluaskan wilayah kekuasaan kekaisaran Jepang. Cita-cita Jepang membentuk Asia Timur Raya mengakibatkan keterlibatannya dalam Perang Dunia II dan sekaligus kehancurannya. Maka ketika Jepang diduduki oleh Amerika Serikat, yang mula-mula dilakukan oleh tentara pendudukan adalah menghilangkan semangat ultranasionalisme melalui pembubaran tentara, mengadili penjahat perang, membubarkan Zaibatsu, dan mengembalikan demokrasi. Setelah Jepang terbebas dari pengaruh ultranasionalisme maka timbul masalah dalam upaya membangun ekonominya kembali. Hal ini karena pembangunan negara tanpa rasa nasionalisme dan patriotisme niscaya akan berhasil dengan cepat.

Suatu kenyataan Jepang mampu bangkit kembali menjadi negara maju seusai pendudukan AS, perekonomian tumbuh secara spektakuler. Apakah Jepang membentuk kembali nasionalismenya pada pasca PD II ? Menarik untuk disimak pernyataan yang dikemukakan Edwin O. Reischauer, bahwa tak ada bangsa yang lebih bersemangat melaksanakan internasionalisme ketimbang orang 
Jepang, atau tegasnya Jepang menanggalkan nasionalisme. ${ }^{4}$ Pada tahun-tahun pertama sesudah Perang Dunia II, orang Jepang jarang mengenakan simbolsimbol nasionalisme. Sebagai contoh, bendera Jepang dan lagu kebangsaan semakin irit penggunaannya dibandingkan negara lain. Kokka shugi dan patriotisme ( sikoku, artinya 'negara cinta' ) sudah banyak ditinggalkan orang Jepang, kata-kata itu hanya digunakan oleh kaum kanan ekstrim. Benarkan Jepang membangun negara tanpa nasionalisme? Sesungguhnya kebanyakan orang Jepang mengidentikkan dirinya dengan negaranya dan sesama orang Jepang.

Homogenitas bangsa Jepang merupakan ciri yang menonjol, sehingga mereka tidak membutuhkan kata patriotisme beserta lambang-lambangnya untuk membina perasaan ini. Semua orang Jepang pasca perang tetap benar-benar bersifat nasionalistik dalam arti yang pokok, mereka tidak peduli pada masalah yang dialami beberapa bangsa lain. Bangsa Jepang memiliki dasar yang tidak ada bandingannya dalam berkorban untuk kepentingan nasional. ${ }^{5}$ Orang Jepang memiliki perasaan "ketersendirian” yang kuat sekali, mereka sadar betul bahwa dirinya sebagai orang Jepang, sedangkan kesan pertama terhadap orang lain adalah "bukan sebagai orang Jepang”. Orang Jepang secara kelompok-kelompok seprofesi dapat menyamakan kepentingan-kepentingannya, baik dalam daerah yang sama maupun berlainan daerah. Hal ini berkembang dalam skala nasional, bahwa penyatuan kepentingan-kepentingan dilakukan juga pada golongan atau kelompok yang berbeda-beda pekerjaan dan pada lingkup geografis yang luas. Maka pada tingkat nasional dapat diwujudkan gabungan kepentingan-kepentingan

\footnotetext{
${ }^{4}$ Edwin O. Reischauer, op.cit., hlm. 543.

${ }^{5}$ Ruth Benedict, loc.cit. Bandingkan dengan Sayidiman Suryohadiprojo. Manusia dan Masyarakat Jepang dalam Perjuangan Hidup, Jakarta: UI-Press, 1982,hlm. 27-28.
} 
yang sama. ${ }^{6}$ Dapat dikatakan mereka masih tetap memiliki jiwa 'ke-Jepang- an' yang tinggi, mereka memiliki ikatan etnisitas yang sangat kuat. Oleh karena itu dapat dikatakan semangat internasionalisme orang Jepang tersebut hanya terdapat pada bagian luarnya saja, sedangkan kedalamannya dapat diketemukan apa yang dikenal 'nasionalisme sejati'.

Sangat jelas bahwa nasionalisme Jepang dibentuk berdasarkan ikatan etnis, budaya dan tradisi negara. Jepang beruntung karena memiliki alat pemersatu bangsa, yaitu kaisar, yang masih tetap efektif pada masa modern. Bangsa Jepang memiliki ketaatan tradisional kepada atasan, terutama kepada kaisar. ${ }^{7}$ Rakyat masih menghormati sosok kaisar seperti pada masa sebelumnya. Pembentukan identitas kebangsaan dilakukan melalui mitologi asal usul bangsa Jepang. Orang Jepang memiliki ikatan emosional yang sangat kuat dengan kaisar, sekalipun mereka perlihatkan dengan sikap yang samar-samar. Selain itu keyakinan bangsa Jepang tentang pemulihan perekonomian dengan industrialisasi untuk membangun ‘negara sejahtera’ yang telah dipraktekkan pada masa Restorasi Meiji dahulu masih relevan. Sehingga usaha pemerintah untuk menanamkan ideologi Shokusan Kogyo atau memajukan industri kepada rakyat tidak sia-sia. Banyak petani meninggalkan pertanian berpindah ke industri, mereka rela bekerja dengan jam kerja yang melebihi batas dan bersedia menerima upah rendah tanpa gejolak sosial. Hal ini sekedar merupakan salah satu contoh tentang patriotisme orang Jepang.

\footnotetext{
${ }^{6}$ Ezra F.Vogel. Jepang Jempol. Jakarta: Sinar Harapan, 1982,hlm. 135-136.

${ }^{7}$ Ruth Benedict, loc.cit.
} 


\section{Nasionalisme Cina}

Sebagaimana dikatakan oleh E.J. Hobsbawm, bahwa di Cina dan Korea terdapat kesatuan politis yang relatif permanen sehingga diakui sebagai "bangsabangsa historis”,maka pergerakan nasional merupakan bentukan-bentukan dari penaklukan imperial. ${ }^{8}$ Di Cina, dapat dikatakan bahwa kemunculan nasionalisme modern tidak dapat menegasikan adanya peranan dinasti Cina yang murni (Han), yaitu dinasti Ming yang digulingkan oleh bangsa Manchu pada tahun 1644. Selain itu juga didorong oleh adanya faktor-faktor penindasan yang dilakukan oleh bangsa Barat terhadap rakyat setempat melalui eksploatasi ekonomi dan buruh, perampasan hak-hak rakyat (pemilikan tanah), penerapan undang-undang Barat dan penerapan cukai yang tidak dipahami masyarakat. Cina memang tidak sepenuhnya dijajah Barat, hanya sebagian wilayah yang dikuasai Barat. Pelakupelaku pergerakan anti asing kebanyakan adalah para loyalis dinasti Ming, baik gerakan yang bertujuan untuk menggulingkan kekuasaan bangsa Manchu maupun bangsa Barat. Bergabungnya pihak kerajaan Ch’ing dalam pergerakan Boxer dalam memerangi bangsa Barat hanyalah menunjukkan kelemahan politik dinasti yang berkuasa tersebut.

Awal penjajahan bangsa Barat di Cina ditandai dengan peristiwa Perang Candu (1839-1840), peristiwa itu memang tidak serta-merta melahirkan nasionalisme Cina. Namun, perjanjian-perjanjian sebagai akibat Perang Candu itulah yang merugikan Cina dan menyebabkan munculnya semangat nasionalisme. Setelah Perang Candu selesai bermunculan gerakan-gerakan anti

${ }^{8}$ E.J. Hobsbowm. Nasionalisme Menjelang Abad XXI. Yogyakarta: Tiara Wacana, 1992, hlm. 73,157. 
bangsa Barat yang dilancarkan oleh kaum loyalis Ming, antara lain : Insiden Tientsin (1870), Peristiwa Margary (1875) dan Gerakan Boxer (1899). Di samping muncul perasaan anti imperalisme Barat, muncul pula perasaan anti bangsa Manchu seperti Pemberontakan Taiping dan Gerakan Serikat Rahasia ( Teratai Putih, Langit dan Bumi, Pedang Besar dan kelompok sosial yang lain ). Pemerintah Ch'ing yang memerintah Cina bukanlah dinasti asli Cina tetapi berasal dari luar Cina, karena itu dipandang sebagai penjajah. Walaupun pemerintah Ch’ing mengadopsi budaya Cina, tetapi diskriminasi tetap dilakukan terhadap bangsa Cina.

Nasionalisme Cina tidak sekedar anti bangsa asing (Barat), melainkan juga semua hal yang berbau Barat, seperti budaya Barat, agama Barat, IPTEK Barat, dan produk-produk Barat. Dengan kata lain perasaan kulturalisme ${ }^{9}$ muncul dan merasuk dalam hati bangsa Cina di tengah-tengah perjalanan pergerakan nasional. Bangsa Cina memiliki rasa percaya diri dan kebanggaan pada budayanya begitu kuat, bahwa budaya Cina lebih unggul dibandingkan dengan budaya lain. Negara Cina dipandang sebagai pusat peradaban, hal ini dapat diketahui dengan adanya konsep "The Middle Kingdom"10, negara-negara lain dianggap belum maju dan bangsa-bangsa lain dianggap masih bar-bar, termasuk bangsa Barat. Masuknya budaya Barat dianggap akan merusak susunan kosmos Cina, sehingga menyebabkan timbulnya pertentangan dalam masyarakat. Penolakan budaya Barat tampak pada pergerakan Boxer. Gerakan itu selain melambangkan anti Barat, juga anti budaya Barat. Kaum Boxer menyerang

\footnotetext{
${ }^{9}$ J.K. Fairbank. East Asia: Tradition dan Transformation. London: George Allen \& Unwin, 1973, hlm. 178.

${ }^{10}$ Ibid.
} 
pasukan asing dengan cara-cara tradisional, yakni mengandalkan keahlian beladiri yang dilengkapi dengan senjata pedang dan tombak. Mereka tidak bersedia menggunakan senjata api tetapi tetap menggunakan pedang dan tombak untuk melawan tentara Barat yang bersenjata api.

Semangat kulturalisme Cina mulai memudar pada masa Revolusi Nasional 1911, Dr. Sun Yat Sen telah menerima pengaruh budaya Barat, terutama fahamfaham Barat tentang nasionalisme, demokrasi dan sosialisme. Hal ini tidak mengherankan karena kaum pergerakan nasional dimotori oleh golongan terpelajar. Meskipun demikian dalam masyarakat Cina masih terdapat anggapan bahwa runtuhnya dinasti Ch'ing karena 'Mandate of Heaven' yang diterimanya telah dicabut kembali. Secara politis Kerajaan Ch'ing sudah tidak memiliki legitimasi lagi. Pandangan ini mudah digunakan untuk memobilisasi massa menentang dinasti Ch’ing.

Bagaimanapun juga pembentukan nasionalisme oleh KMT telah berhasil dan dilanjutkan dengan pembentukan nation state Cina, yakni Republik Nasionalis Cina. Revolusi 1911 menjadi pendorong semangat menentang Barat dan Ch'ing serta mendirikan negara. Republik yang masih muda ini ditempa oleh ujian-ujian berat yang mengarah pada disintegrasi nasional. Pertama, perpecahan di kalangan militer Peiyang di utara (1921-1927), yaitu : kelompok Anhwei (pimpinan Jenderal Tuan chi-jui), kelompok Chihli (Jenderal Feng Kuochang) dan kelompok Fengtian (Jenderal Chang Tsao Lin). Di selatan juga terdapat kelompok Yunnan dan kelompok Kwangsi, masing-masing dipimpin oleh Jenderal Tang Jiyao dan Lung Jung-ting. Kaum sparatis itu ingin mendirikan 
negara dalam negara. Integrasi nasional terjadi setelah Peking dikuasai (1928) oleh pasukan Chiang Kai-shek dari kubu nasionalis. Kedua, pertentangan antara golongan nasionalis dan komunis yang berakibat terbentuknya dua negara berdaulat, yaitu RRC dan Taiwan.

Pembentukan nasionalisme dilakukan juga oleh kelompok di bawah pimpinan Mao Zedong, yakni dengan menggunakan ajaran Marxisme-Leninisme yang kemudian dimodifikasi menjadi ajaran Maoisme. Meskipun demikian ajaran Maoisme belum dapat diterima oleh seluruh bangsa Cina. Bahkan menimbulkan pertentangan dan perpecahan bangsa yang mengakibatkan terbentuknya "Dua Cina”, yaitu Cina Daratan (RRC) dan Cina Kepulauan (Taiwan). Keduanya memiliki dasar ideologi politik yang berbeda, yaitu komunis dan nasionalis. Masing-masing telah menemukan bentuk nasionalismenya, yaitu nasionalisme Cina dan nasionalisme Taiwan. Kesadaran kebangsaan masing-masing pihak itu lahir dilandasi oleh nasionalisme, dan ini merupakan manifestasi dari pertentangan dan konflik kepentingan daripada sekedar hasil solidaritas di dalam atau antarkelompok. Memang, kedua perbedaan ideologi itu pernah bersatu dalam menentang pendudukan Jepang (1937), tetapi hanya berusia pendek dan berpecah lagi hingga kini. Masing-masing telah menemukan local genius-nya sendirisendiri. Sehingga reunifikasi “Dua Cina” masih menjadi persoalan Cina.

Pembentukan "Satu Cina” dengan formula “one country, two system” yang ditawarkan RRC belum bisa diterima oleh Taiwan. Kesamaan etnis atau ras tidak diragukan lagi, namun homogenitas bangsa Cina yang telah lama terbentuk sudah tidak berfungsi lagi dalam kasus itu. Perbedaan dalam identitas bangsa dan 
loyalitas politis menyebabkan upaya reunifikasi mengalami kegagalan. Pemberian status Taiwan sebagai Daerah Administrasi Khusus dengan otonomi yang luas, dipandang oleh pihak Taiwan tetap tidak realistis. Pemecahan masalah Taiwan bukan hal yang mudah, suatu alternatif yang bisa dilakukan adalah menyamakan loyalitas politis dan menemukan identitas baru yang dapat mendasari terbentuknya “nasionalisme Cina”. Memang, jalan masih panjang dan masih mungkin menambah alat pemersatu yang baru selain politik. Persamaan ideologi negara yang baru andaikata bisa diciptakan juga belum pasti dapat menyatukan "dua Cina”. Selama para pemimpin negara tidak memiliki political will dan kesadaran “kebangsaan Cina” yang tinggi untuk berintegrasi maka reunifikasi tetap menjadi impian belaka.

\section{Nasionalisme Korea}

Korea merupakan negara yang terus-menerus diperebutkan oleh Cina, Jepang dan Rusia, karena memiliki letak yang strategis. Perebutan wilayah itu berhenti setelah Jepang berhasil menguasai Korea (1910-1945). Ketika itu pula Kerajaan Choson dan kedaulatan bangsa Korea berakhir. Selama 35 tahun Korea menjadi jajahan Jepang, maka pergerakan nasional muncul untuk mengusir kekuatan imperial Jepang. Kaum nasionalis baik yang ada di luar negeri maupun yang tinggal di dalam negeri banyak dipengaruhi oleh anjuran Woodrow Wilson bahwa setiap bangsa berhak "menentukan nasibnya sendiri”. 
Penjajahan Jepang itu segera mendapatkan reaksi dari rakyat Korea, seperti pembentukan pasukan kemerdekaan, Chamuibu, Jonguibu dan Sinminbu. ${ }^{11}$ Pergerakan nasional meletus pada 1 Maret 1919 bertepatan dengan peringatan hari wafatnya Raja Kojong. Ketika itu pula dibacakan teks proklamasi kemerdekaan Korea di taman Pagoda. Tradisi negara menjadi elemen untuk menyatukan rakyat, dan karena itu mendasari munculnya nasionalisme. Demonstrasi itu mendapat reaksi keras dari Jepang, tetapi kaum nasionalis tidak menyurutkan gerakannya. Para aktivis di luar negeri yang tergabung dalam Asosiasi Nasionalis Korea di Hawai dan Asosiasi Pemuda Korea di Shanghai, melakukan upaya mencari pengaruh bagi kemerdekaan Korea di luar negeri melalui Perjanjian Versailles. Mereka juga membentuk pemerintahan-pemerintahan di pengasingan, sedangkan Gerakan Pemuda Nasionalis di Korea menghimpun dana untuk kepentingan perjuangan.

Antara tahun 1926 - 1945 gerakan anti Jepang sering kali dilakukan secara fisik oleh pemuda, petani, buruh, dan gerakan tentara revolusioner rakyat Korea. Jepang mempraktekkan devide et impera, karena itu kaum nasionalis mendirikan wadah organisasi yang bernama Sinkanhoe (1927), tujuannya menyatukan kaum pergerakan tanpa membedakan ideologi. Rupanya organisasi itu kurang berhasil sehingga kaum pergerakan bergerak sendiri-sendiri. Golongan petani melawan tuan-tuan tanah yang memihak Jepang, bahkan melancarkan pemberontakan di Danchun (1930). Kaum buruh melancarkan pemogokan di Wonsan (1929). Gerakan revolusioner yang berdasarkan ideologi komunisme dilancarkan oleh

\footnotetext{
${ }^{11}$ Shin Yong-ha. Modern Korean History and Nationalism Korean Studies. Seoul: Jimoondang , 2002, hlm.135.
} 
Kim Il Sung. Gerakan itu dengan cepat meluas dan menjadi gerakan massa pemuda, mahasiswa, buruh dan tani. Di bawah koordinasi pemimpin komunis itu kemudian pada tahun 1932 didirikan Partai Komunis, Liga Pemuda Komunis, organisasi-organisasi massa, dan tentara revolusioner rakyat Korea (1934). Tiga tahun kemudian kekuatan revolusioner ini telah berani menyerang benteng pertahanan tentara Jepang (Bonchonbo), dan kemudian bertepatan dengan kekalahan Jepang dalam PD II pasukan revolusioner bekerja sama dengan tentara merah Uni Soviet untuk kemerdekaan Korea. Sementara itu tentara pemerintahan sementara Republik Korea telah bersiap-siap melawan tentara Jepang di Semenanjung Korea menyusul pengumuman Jepang menyerah tanpa syarat.

Bangsa Korea gagal memperoleh kemerdekaan pada 15 Agustus 1945, karena Sekutu sebagai pemenang perang membagi Korea menjadi dua, yakni Korea Utara di bawah kekuasaan Uni Soviet dan Korea Selatan dikuasai Amerika Serikat. Keputusan ini merupakan hasil pembicaraan di PBB yang mengandung makna menegasikan perjuangan nasional Korea. Oleh karena itu organisasi sosial dan politik berusaha mempersiapkan rancangan pembentukan negara baru. Pada tahun 1948 dua negara baru didirikan, yaitu Republik Korea di selatan dan Republik Demokrasi Rakyat Korea di utara. Pemerintahan di Korea Utara dibentuk berdasarkan sistem komunisme, sedangkan Republik Korea berdasarkan demokrasi dan kapitalisme. Perbedaan ideologi ini merupakan salah satu penyebab timbulnya Perang Korea, dan hambatan dalam upaya reunifikasi Korea hingga saat ini. Sama halnya dengan masalah Taiwan, konflik di Korea tidak berdasarkan perbedaan etnis atau ras tetapi masing-masing loyalitas politik yang 
mengikat mereka. Kesadaran kebangsaan sebagai manifestasi dari konfrontasi dan konflik kepentingan yang muncul seolah-olah mereka bukan bangsa yang sama. Alhasil, pertentangan politik tersebut menjadi suatu faktor yang mendorong terbentuknya “nasionalisme Korea Selatan” dan "nasionalisme Korea Utara” di masa perang saudara.

Korea Selatan pasca perang saudara di samping masih berusaha mencari jalan menuju reunifikasi, juga melakukan pembangunan ekonomi yang sangat cepat dengan program "lompatan besar ke depan”. Korea termasuk terlambat dalam membangun industrinya, maka peranan negara sangat dibutuhkan untuk merebut pasar. Pembangunan ekonomi berorientasi pertumbuhan, dan karena itu diperlukan landasan yang kokoh, yaitu demokrasi dan patriotisme murni. ${ }^{12}$ Presiden Park Chung Hee menanamkan idenya tentang Sae-maul Undong (Gerakan Masyarakat Baru) kepada seluruh rakyat Korea Selatan. Gerakan ini dilandasi oleh falsafah politik kepemimpinan yang meliputi kepercayaan dan tekad untuk mengentaskan kemiskinan. Tujuan gerakan ini adalah untuk mewujudkan kemandirian masyarakat desa agar dapat menciptakan New Village Movement, Independence, Self-help, dan Mutual Cooperation. Pada hakekatnya gerakan Sae-maul Undong itu merupakan manifestasi dari jiwa kebersamaan rakyat Korea dalam memerangi kemiskinan. ${ }^{13}$ Kesadaran rakyat Korea sebagai warga negara dan rasa patriotisme yang tinggi diperlihatkan dalam mencapai tujuan menjadi bangsa terhormat di dunia. Tentulah hal ini dapat dikatakan sebagai bentuk baru nasionalisme Korea Selatan. Dalam gerakan Sae-maul

\footnotetext{
${ }^{12}$ Inilah Korea, Seoul: Dinas Penerangan Korea, 1976, hlm.76.

${ }^{13}$ Ibid.,hlm. 74-75.
} 
Undong tersebut terdapat loyalitas politik dan ikatan rasa kesukuan yang ditransfer kepada apa yang disebut “bangsa Korea Selatan”.

Loyalitas politik dan etnisitas terdapat juga pada bangsa Korea di Utara, namun untuk membentuk "nasionalisme Korea” tidak didukung oleh homogenitas etnik yang lebih besar sehingga nasionalisme itu belum dapat terwujud. Kesamaan budaya lama dan ikatan kesukuan yang lebih besar dapat dikatakan pudar, sementara perbedaan budaya baru yang kontradiktif masih sangat kuat. Oleh karena itu upaya untuk menyatukan kembali “dua Korea” tidak berjalan lancar. Memang, akhir-akhir ini cita-cita reunifikasi Korea semakin nyata di depan mata, meskipun untuk mewujudkan "satu Korea” masih merupakan persoalan besar. Pendekatan kedua pemimpin Korea, Kim Jong-il dari Pyongyang dan Roh Moo-hyun dari Seoul adalah jalan lurus menuju reunifikasi. George Junus Aditjondro, mengatakan bahwa reunifikasi akan menghasilkan super-power baru di berbagai bidang ekonomi ${ }^{14}$. Pendapat ini menunjukkan optimisme, tentu kalau AS tidak bersedia mengurangi tekanan dan perlakuan yang tidak pantas kepada Korea Utara dalam bidang perdagangan. Perselisihan dagang Asia TimurAS boleh jadi memicu reaksi-reaksi nasionalistik negara-negara di Asia Timur. Tanda-tandanya telah tampak, yaitu munculnya gerakan anti-Amerika yang dilakukan oleh mahasiswa dan pekerja Korea Utara belum lama ini. ${ }^{15}$

\section{E. Kesimpulan}

\footnotetext{
${ }^{14}$ Seputar Indonesia, Selasa 23 Oktober 2007, hlm.10.

${ }^{15}$ Jurnal Studi Jepang, Vol.1 No.2 1992. Yogyakarta: Pusat Studi Jepang UGM, hlm. 8.
} 
Pembentukan nasionalisme mengalami perkembangan sesuai dengan zamannya, termasuk di kawasan Asia Timur. Pada pertengahan abad ke-20 pembentukan nasionalisme yang didasarkan pada gabungan unsur etnisitas dan loyalitas politik masih terlihat dengan jelas di kawasan Asia Timur. Akan tetapi menjelang akhir abad ke-20 kedua unsur itu hanya terdapat di Jepang, sedangkan di Cina dan Korea hanya aspek loyalitas politik yang digunakan untuk membentuk nasionalisme. Di Jepang, kedua unsur itu telah menyatu pada diri orang Jepang, sehingga apa yang dilakukan oleh orang Jepang yang berorientasi internasionalisme tidak melenyapkan identitas nasional. Mereka sadar betul bahwa dirinya adalah orang Jepang. Pemerintah Jepang sangat memperhatikan pembentukan kepribadian bangsa terutama pada generasi penerus. Hal ini terlihat dalam proses pembelajaran di Sekolah Dasar hingga Sekolah Menengah, bahwa pelajaran tentang cinta tanah air hingga kini dimasukkan di dalam kurikulum.

Sementara itu di Cina dan Korea pada masa yang sama juga berlangsung proses pembentukan nasionalisme dengan menggunakan unsur etnisitas dan loyalitas politik. Namun setelah terbentuknya “dua Cina” dan “dua Korea”, maka muncul upaya untuk membentuk kembali "satu” Cina dan "satu” Korea. Dalam rangka reunifikasi itu hingga kini masih terdapat kesulitan untuk mencari bentuk baru nasionalisme yang dapat diterima oleh bangsa-bangsa yang bersengketa. Kedua unsur tersebut tidak dapat digunakan sebagai landasan untuk menyatukan bangsa Cina dengan Taiwan, dan Korea Selatan dengan Korea Utara. Dengan demikian hingga saat ini pembentukan "nasionalisme Cina” dan "nasionalisme Korea” belum dapat terwujud. 


\section{Daftar Pustaka}

Abdullah Zakaria Ghazali (et.al.). Sejarah Asia Tenggara, Asia Selatan, dan Asia Timur. Kuala Lumpur: Fajar Bakti, 2000.

Barrington Morre, Jr. Social Origin of Dictatorship and Democracy. Boston: Beacon Press, 1967.

Benedict, Ruth. Pedang Samurai dan Bunga Seruni, Pola-Pola Kebudayaan Jepang. Jakarta: Sinar Harapan, 1979.

Fairbank, J.K. East Asia: Tradition dan Transformation. London: George Allen \& Unwin, 1973.

Hobsbowm, E.J. Nasionalisme Menjelang Abad XXI. Yogyakarta: Tiara Wacana,1992.

Inilah Korea. Dep.Pend-Penerangan Korea,1976.

Jurnal Studi Jepang Vol.1, No.2.1992. Yogyakarta: Pusat Studi Jepang.

Mudji Hartono.”Dasawarsa Pertama Restorasi Meiji (1868-1878): Sebuah Kasus Revolusi Dari Atas”, dalam Informasi No.2 Th.XVII, 1987.

Reischauer,E.O. Manusia Jepang. Jakarta: Sinar Harapan, 1982.

Sayidiman Suryohadiprojo. Manusia dan Masyarakat Jepang dalam Perjuangan Hidup. Jakarta : UI-Press, 1982.

Seputar Indonesia, Selasa 23 Oktober 2007.

Vogel, Ezra,F. Jepang Jempol. Jakarta: Sinar Harapan, 1982. 